\title{
金井賞受賞講演：
}

\section{地域の女性を中心とした，「食と農」を 次世代に伝える取り組み}

\author{
加 藤 和 奈*
}

\section{は じめに}

今，私たちを取り巻く環境は，新型コロナウ イルス感染症の感染拡大により, JA 女性組織 活動の中止や縮小を余儀なくされ, 不安な日々 が続いています。その中で, 最善を尽くしてい ただいている医療関係者の皆さまに敬意を表す るとともに，心より感謝申し上げます。そし て, 感染症が拡大する中, 農畜産物の供給を絶 やさないよう生産し出荷を続ける農家は私たち の誇りです。今，私たちにできることは，自分 や自分の大切な人を守るための責任ある行動だ ということを忘れず，新たな生活様式の中での JA 女性組織活動に模索の日々が続いていま す。

\section{JA あいち海部管内の概要}

JA あいち海部は, 愛知県の西部に位置し, 北は岐阜県, 西は三重県に隣接し，南は名古屋 港の港湾海域を臨む, 木曽川下流の沖積デル夕 地域です。豊かな水と肥沃な土畩に恵まれた管 内の農業は, 水稲作が全作付面積の 6 割以上を 占め, 愛知県下でも有数の水田地帯となってい ます。私の住む弥富市は, 管内の南部に位置 し，干拓で作られた地域が多く，1959年 9 月の 伊勢湾台風の折には海岸や河川の堤防が決壊し て甚大な被害を受けました。この被害を教訓に 台風シーズン前に刈り取る早場米に力を注ぎ, 現在では夏の猛暑が続く中, 愛知県内で一番早

* = 496-0876 愛知県津島市大縄町9-63 JA あいち海部女性部部長
い新米を出荷しています。

\section{女性 部の設立}

2007年 4 月 1 日の合併により JA あいち海部 が設立されました。その 3 年後に「女性が元 気！地域が元気！」をスローガンに掲げ，「食 農教育活動」・「健康づくり活動」・「環境問題活 動」の重点活動方針のもと JA あいち海部女性 部の活動が始まりました。

\section{生涯現役健幸活動}

当初, 食習慣や運動習慣の改善や生きがいづ くり，健康寿命の延伸を目指し「JA あいち海 部 健康会議」を毎年開催するものの「今さら」 と自分自身の食習慣や運動習慣の改善は後回し にする姿勢が多くの部員から見られました。

そこで, 愛知県の JA 女性組織で構成する JA あいち女性協議会の役員会において議題に 挙げると, 県内の女性組織でも同じ傾向が見ら れたことから「生涯現役として健康で幸せに暮 らせるように」との願いを込めて, JA あいち 女性協議会の重点活動のひとつを「生涯現役健 幸活動」と名称変更しました。

まずは，自らの健康寿命の目標を設定し自分 の健康を守るための活動に取り組み, さらには 家族の健康を守るため食習慣の見直しにも取り 組むよう積極的に呼びかけています。

毎年 6 月には, JA 愛知中央会や JA 愛知厚 生連，愛知県農協健康保険組合等と「JA あい ち健康会議」を共同開催し, 愛知県内の JA 女 性部員をはじめ組合員に対する意識啓発を行 なっています。 


\section{健全な食と農を地域につなぐ活動}

近頃では，ライフスタイルが多様化し若い世 代の米離れが進んでいます。

愛知県は，工業のイメージが強い県ですが農 業も盛んです。工業製品は同じものを繰り返し 生産することができますが，農産物は 1 年に 1 回しか収穫できないものもたくさんあります。 その上，自然との闘いがあります。

弥富市では伊勢湾台風の教訓から毎年, 県下 最速で「あいちの新米」が出荷されている利点 を活かし2015年から『初めて作った料理がおに ぎりなら，一生ごはんが大好きな子になる』と の願いを込め,「はじめての料理は『おにぎり』 プロジェクト」の取り組みを始めました。JA 女性部が親と子どもの心に残る「初めての料理 記念日」をどこよりも早い新米の「おにぎり」 で祝うイベントです。

食べることは，生きること。「食」が育てる のは「身体」と「心」なら，土に触れ自分が大 切に育てた農作物に感謝して食べる喜びをもっ と子どもたちに，そして家族に知ってもらいた いのです。

JA 女性組織が取り組む様々な「健全な食と 農を地域につなぐ活動」は, 子どもや孫, さら
には100年先を生きる子どもたちに豊かな「食 と農」をつなぐ活動であると自覚と自信と誇り をもって取り組んでいます。将来を生きる子ど もたちが耕す未来の田畑は, 今の私たちに託さ れているのです。先人が, 伊勢湾台風の泥海か ら復興してくれた田畑のように。

\section{むすびに}

新型コロナウイルス感染症は世界経済に大き な影響を与えました。そして，人と人のつなが りにも距離ができました。JA 全国女性組織協 議会は, SDGs の「誰一人取り残さない」世界 の実現を目指しています。感染者数の報道に振 り回されるのではなく, 罹患された方に差別や 偏見，誹謗中傷するなど，心まで病むことのな い優しい世の中であってほしいと願います。

今, 全国の JA 女性組織の基盤が摇らぐ深刻 な事態となっています。どんな状況にあっても 先人が困難を乗り越えてきたように，私たちに も「できることが必ずある」「できることから はじめよう」と呼びかけています。

食は命。だからこそ，そこに息づく農業の大 切さを地域に，そして次世代に伝えて行くこと が私たちに課された大きな役割だと改めて思い ます。 